\title{
Utility of WHOQOL-BREF in measuring quality of life in Sickle Cell Disease
}

\author{
Monika R Asnani*1, Garth E Lipps² and Marvin E Reid ${ }^{1}$
}

\author{
Address: ${ }^{1}$ Sickle Cell Unit, Tropical Medicine Research Institute, University of the West Indies, Mona Campus, Kingston 7, Jamaica and \\ ${ }^{2}$ Department of Psychology, Sociology and Social Work, University of the West Indies, Mona Campus, Kingston 7, Jamaica \\ Email: Monika R Asnani* - monika.parshadasnani@uwimona.edu.jm; Garth E Lipps - garth.lipps@uwimona.edu.jm; \\ Marvin E Reid - marvin.reid@uwimona.edu.jm \\ * Corresponding author
}

Published: 10 August 2009

Health and Quality of Life Outcomes 2009, 7:75 doi:10.1186/1477-7525-7-75

This article is available from: http://www.hqlo.com/content/7///75

(C) 2009 Asnani et al; licensee BioMed Central Ltd.

This is an Open Access article distributed under the terms of the Creative Commons Attribution License (http://creativecommons.org/licenses/by/2.0), which permits unrestricted use, distribution, and reproduction in any medium, provided the original work is properly cited.
Received: 18 March 2009

Accepted: 10 August 2009

\begin{abstract}
Background: Sickle cell disease is the commonest genetic disorder in Jamaica and most likely exerts numerous effects on quality of life (QOL) of those afflicted with it. The WHOQOL-Bref, which is a commonly utilized generic measure of quality of life, has never previously been utilized in this population. We have sought to study its utility in this disease population.

Methods: 49I patients with sickle cell disease were administered the questionnaire including demographics, WHOQOL-Bref, Short Form-36 (SF-36), Flanagan's quality of life scale (QOLS) and measures of disease severity at their routine health maintenance visits to the sickle cell unit. Internal consistency reliabilities, construct validity and "known groups" validity of the WHOQOLBref, and its domains, were examined; and then compared to those of the other instruments.

Results: All three instruments had good internal consistency, ranging from 0.70 to 0.93 for the WHOQOL-Bref (except the 'social relationships' domain), 0.86-0.93 for the SF-36 and 0.88 for the QOLS. None of the instruments showed any marked floor or ceiling effects except the SF-36 'physical health' and 'role limitations' domains. The WHOQOL-Bref scale also had moderate concurrent validity and showed strong "known groups" validity.

Conclusion: This study has shown good psychometric properties of the WHOQOL-Bref instrument in determining QOL of those with sickle cell disease. Its utility in this regard is comparable to that of the SF-36 and QOLS.
\end{abstract}

\section{Background}

Sickle cell disease (SCD) is the commonest genetic disorder in Jamaica with the sickle hemoglobin (HbS) gene being present in about $10 \%$ of the population. It includes a variety of pathological conditions [1] and affects the individual throughout their life cycle. In Jamaica, SCD has become a significant indirect cause of maternal mortality [2] and contributes as a causative factor to $0.7 \%$ of cases of chronic renal failure [3]. It has also been presented as one of the 10 most common causes of sudden death in Jamaica accounting for $2.5 \%$ of cases [4]. Among those with homozygous sickle cell disease (SS) in Jamaica, there is a $50 \%$ survival to 30 to 40 years. Median survival is calculated at 53 years for men and 58.5 for women [5].

SCD carries a huge psychosocial burden impacting on physical, psychological, social and occupational wellbeing as well as levels of independence [6-14]. Psycholog- 
ical complications in patients with SCD mainly result from the impact of pain and symptoms on their daily lives and society's attitudes towards them [15-17]. Generally, there is increased psychological morbidity such as depression and poor coping $[9,10,18-22]$, and poorer quality of life (QOL) $[9,14,23]$.

The Short-Form 36 (SF-36) has been validated for measuring QOL in this population [24], but the World Health Organization Quality of Life- BREF (WHOQOL-BREF) has never been studied in these patients. Whereas the SF36 provides some measure of functional status along with health related QOL, the WHOQOL-BREF measures relatively broader and totally subjective domains [25-27]. Its particular strength lies in the fact of its cross-cultural development employing elements of emic and etic perspectives [28], and as the Jamaican population represents a forging of different ethnicities as well as distinct cultures [29], the WHOQOL-Bref may prove to be a stronger measure of QOL. The Flanagan's quality of life scale (QOLS) is a generic scale but has had particular adaptation for use among persons with chronic diseases [30]. A comparison of these generic instruments will allow further study of their possible weaknesses and strengths. Therefore, the specific aims of this study are to: i) assess the properties of WHOQOL-BREF in SCD; and ii) compare the properties of the WHOQOL-BREF, SF-36 and QOLS in SCD.

In the current study we expected that the WHOQOL physical subscale should be strongly correlated $(r \geq 0.50)$ with SF-physical health, role limitations and total scores, but less correlated $(\mathrm{r} \leq 0.30)$ with SF-mental health scores as this subscale assesses the physical state of patient's quality of life. We expect a smaller correlation $(r \geq 0.30)$ with clinical indicators such as haemoglobin and serum lactate dehydrogenase (LDH). WHOQOL-psychological health domain may be strongly correlated $(r \geq 0.50)$ with the SF-mental health, SF-36 total score and the QOLS, but only moderately ( $\mathrm{r} \leq 0.30$ ) with SF-physical health and role limitations subscales. The WHOQOL-social relations and environment subscales are expected to be strongly correlated $(r \geq 0.50)$ with the SF-mental health subscale, the SF-36 total score and the QOLS scale, but less $(\mathrm{r} \leq$ 0.30 ) with the SF-physical and role limitations subscales, and $(\mathrm{r} \leq 0.30)$ with haemoglobin and LDH. Finally, we expect the total WHOQOL-Bref score to be strongly correlated $(r \geq 0.50)$ with the total SF-36 and QOLS scores.

\section{Methods}

\section{Study population}

This was designed as a cross-sectional study. The Sickle Cell Unit (SCU) in Kingston operates Jamaica's only comprehensive sickle cell centre. All adults over the age of 18 years, registered at the SCU for at least 1 year, and present- ing for health maintenance visit from January to June 2005 were invited to take part and none declined.

\section{Study Instruments}

The SF-36, QOLS and WHOQOL-BREF (U.K.version) were interviewer-administered (as only about $80 \%$ of Jamaicans are considered to be functionally literate [31]) to all participants after they had signed an informed consent form. Data were also collected on age, sex, genotype, marital status, level of education achieved, employment status and occupation.

\section{Study Instruments}

In past research, the WHOQOL-BREF has shown good to excellent reliability and validity, and has four domains: physical, psychological, social and environment [32]. Thomas et al [14], in their qualitative work with patients who have SCD, have identified themes that are quite similar to the core domains of the WHOQOL.

The psychometric properties of the SF-36 have been studied in the Jamaican population with SCD and it shows a slightly different component structure [33] yielding three distinct subscales: physical health, mental health and role limitations.

QOLS is a reliable and valid 16 item generic instrument [34]., and was selected for use as it has been extensively used in chronic conditions and provides a subjective, global evaluation of QOL.

Data on participants' clinical variables, such as frequency of painful crises in past year, haemoglobin levels, serum creatinine and LDH levels, were obtained from their medical records. The study was granted ethical approval by the University of the West Indies/University Hospital of the West Indies, Faculty of Medical Sciences Ethics Committee.

\section{Statistical approach}

All data were initially captured into Epidata ${ }^{\circledR}$ for Windows and then analyzed with Stata ${ }^{\mathrm{TM}}$ statistical software for Windows version 8.2 [35].

Domain scores for the WHOQOL were transformed to a 4-20 score according to accepted guidelines [36]. Cronbach's alpha values of .70 and over were deemed acceptable [37]. The floor and ceiling effects were measured for the scales and their domains with floor effect being the percentage of subjects with the lowest possible domain scores and the ceiling effect being the percentage of subjects with the highest possible domain scores.

The psychometric properties were further tested by measuring the "known-groups" construct validity. The pres- 
ence of painful crises in SCD is a very prevalent and severe complication of the disease [38,39], and those with higher pain rates tend to die earlier than those with lower pain rates [40]. Painful crises were defined as presence of bony pains requiring opioid analgesics for relief, and categorized (less than or equal to 3 episodes per year or greater than 3 episodes for the year). T-test was used to test whether the scores in the three instruments could discriminate among different categories.

Pearson's correlations were used to determine the level of agreement between the three instruments, as well as with markers of disease severity. As a general guideline, correlations from 0.00 to 0.25 indicate little or no relationship, from 0.25 to 0.50 a fair degree of relationship, from 0.50 to 0.75 a moderate to good relationship, and above 0.75 a good to excellent relationship [41].

\section{Results}

\section{Demographics and clinical characteristics}

A total of 491 patients participated (Table 1), consisting of $43 \%$ males and $57 \%$ females. The mean age was 31.3 years \pm 9.6 years with a range from $18-70$ years. The commonest genotypes were 68\% SS (Homozygous S Disease) disease and 21.5\% SC (Heterozygous S-C Disease). Most were 'single' (88\%) with only $10 \%$ being 'married'. Only $51.5 \%$ were employed currently. $54 \%$ had a secondary

Table I: Demographic and clinical characteristics of the study population $(n=49 I)$

\begin{tabular}{ll}
\hline Variable & \\
\hline Sex, M: F (\%) & $210(42.7): 28 I$ (57.3) \\
Age, mean years (SD) & $31.3(9.6)$ \\
Genotype, \% & 68.1 \\
$\quad$ SS & 21.5 \\
SC & 10.4 \\
$\quad$ Others & \\
Education, (\%) & $72(14.7)$ \\
$\quad$ Primary & $266(54.2)$ \\
$\quad$ Secondary & $119(24.2)$ \\
Vocational training & $30(6.1)$ \\
$\quad$ Tertiary & $253(51.5): 238(48.5)$ \\
Employment status, Y: N (\%) & $431(87.8)$ \\
Marital Status, (\%) & $48(9.8)$ \\
$\quad$ Single & $12(2.4)$ \\
$\quad$ Married & $9.0(2.2)$ \\
Other & $4.6(4.3)$ \\
Haemoglobin g/dl, mean (SD) & $391.73(193.2)$ \\
Fetal Haemoglobin \%, mean (SD) & $60.4(25.4)$ \\
Lactate Dehydrogenase IU/L, mean (SD) & \\
Serum Creatinine $\mu$ mol/L, mean (SD) & $412(83.9)$ \\
Painful Crises, $n$ (\%) & $79(16.1)$ \\
0-3 per year & \\
More than 3 per year & \\
\hline
\end{tabular}

education, $24 \%$ had vocational training and $6 \%$ had a tertiary education.

The mean haemoglobin was $9.0 \pm 2.2 \mathrm{gm} / \mathrm{dl}$; and fetal haemoglobin was $4.6 \pm 4.3 \%$. The mean serum creatinine and $\mathrm{LDH}$ were $60.4 \pm 25.4 \mu \mathrm{mol} / \mathrm{L}$ and $391.7 \pm 193.2 \mathrm{IU} /$ $\mathrm{L}$ respectively. $83.9 \%$ had $0-3$ painful crises for the past year and $16.1 \%$ had greater than 3 .

\section{Psychometric properties of the WHOQOL-Bref, QOLS and SF-36}

The baseline means, standard deviations, minimum/maximum and internal consistency reliability coefficients for all three instruments and their domains are summarized in Table 2. All scales had moderate Cronbach's alpha scores, ranging from 0.70 to 0.93 , except the WHOQOLsocial relationship domain $(0.66)$. The mean scores for the WHOQOL-physical health and WHOQOL-environment were lower than the other domain scores. The SF-36 and QOLS had generally higher reliability coefficients than the WHOQOL-Bref. Most domains had no marked floor or ceiling effects $(<1 \%)$, exceptions being WHOQOL-social relations (ceiling effect $=3.9 \%$ ), SF-mental health and SF-role limitations domains (ceiling effects $\sim 19 \%$ ).

Table 3 shows the known-groups validity where the mean scores decreased, meaning lower quality of life on each scale/domain, as frequency of painful crises increased (All $\mathrm{p}<0.01$ for ANOVA).

\section{Correlation analyses}

Table 4 demonstrates the correlations of the WHOQOLBref with SF-36, QOLS and clinical variables. The total SF36 and WHOQOL-Bref scores had an acceptable positive correlation (0.64). The WHOQOL-Bref domains showed moderate correlations with SF-36-mental health, ranging from 0.51 for WHOQOL-social relationships to 0.59 for WHOQOL-psychological, and with the total SF-36 score (0.47-0.53). They had much stronger correlations with the QOLS score, ranging from 0.43 for WHOQOL-physical to 0.71 for WHOQOL-environmental. The WHOQOL total score correlation with the QOLS score was high at 0.75 .

As expected, the clinical variables showed significant correlations with WHOQOL-physical health: -0.34 with $\mathrm{LDH}$ and 0.34 with haemoglobin. These variables also had smaller, significant correlations with the total WHOQOL score.

\section{Discussion}

The main purpose of this paper was to assess the utility of this instrument in patients with SCD living in Jamaica. In all of its performance measures, the WHOQOL-Bref has 
Table 2: Descriptive Statistics of all three measures and their domains*

\begin{tabular}{|c|c|c|c|c|c|c|c|}
\hline & Cronbachs Alpha & Minimum & Maximum & Mean & Std. Deviation & Floor effect (\%) & Ceiling effect (\%) \\
\hline WHOQOL-Physical & 0.87 & 7.43 & 20.00 & 13.96 & 2.71 & 0.2 & 0.8 \\
\hline WHOQOL-Psychological & 0.82 & 6.67 & 19.33 & 14.18 & 2.12 & 0.2 & 0.4 \\
\hline $\begin{array}{c}\text { WHOQOL- Social } \\
\text { Relations }\end{array}$ & 0.66 & 5.33 & 20.00 & $14.9 \mid$ & 2.77 & 0.2 & 3.9 \\
\hline WHOQOL-Environment & 0.81 & 7.50 & 19.00 & 13.38 & 2.24 & 1.0 & 0.2 \\
\hline Total WHOQOL Score & 0.81 & 34.17 & 76.34 & 56.43 & 7.87 & 0.2 & 0.2 \\
\hline SF 36-Physical Health & 0.86 & 10 & 30 & 26.46 & 3.49 & 0.4 & 19.1 \\
\hline SF36-Mental Health & 0.93 & 15 & 45 & 32.45 & 6.21 & 0.2 & 0.4 \\
\hline SF36-Role Limitations & 0.90 & 12.2 & 42 & 34.54 & 7.13 & 0.2 & 19.2 \\
\hline Total SF36 Score & 0.70 & 48.2 & 117 & 93.46 & $|3.8|$ & 0.2 & 0.4 \\
\hline QOLS Score & 0.88 & 38 & 114 & 78.0 & 10.8 & 0.2 & 0.2 \\
\hline
\end{tabular}

* Higher scores reflect better quality of life on each domain of all measures

Table 3: Scale and domain scores for categories of painful crises

\begin{tabular}{|c|c|c|c|}
\hline & $\begin{array}{c}0-3 \text { painful crises/year } \\
(N=4 \mid 2)\end{array}$ & $\begin{array}{c}>3 \text { painful crises/year } \\
(\mathrm{N}=79)\end{array}$ & $\mathrm{p}$-value \\
\hline WHOQOL-Physical & $14.3(|4.0| 4.5)$, & $12.3(11.8,12.8)$ & $<0.001$ \\
\hline WHOQOL-Psychological & $14.3(14.1,14.5)$ & $13.6(13.1,14.1)$ & 0.009 \\
\hline WHOQOL- Social Relations & $15.1(14.8,15.3)$ & $14.1(13.4,14.7)$ & 0.004 \\
\hline WHOQOL-Environmental & $13.5(13.3,13.7)$ & $12.5(11.9,13.1)$ & $<0.001$ \\
\hline Total WHOQOL Score & $57.2(56.4,57.9)$ & $52.6(50.9,54.3)$ & $<0.001$ \\
\hline SF 36-Physical Health & $26.7(26.4,27.0)$ & $25.2(24.4,26.0)$ & $<0.001$ \\
\hline SF36-Mental Health & $33.1(32.6,33.7)$ & $28.9(27.5,30.3)$ & $<0.001$ \\
\hline SF36-Role Limitations & $35.6(35.1,36.4)$ & $28.2(26.6,29.9)$ & $<0.001$ \\
\hline Total SF36 Score & $95.6(94.4,96.8)$ & $82.3(78.9,85.7)$ & $<0.001$ \\
\hline QOLS Score & $78.7(77.6,79.7)$ & $74.6(71.9,77.1)$ & 0.002 \\
\hline
\end{tabular}

Values are mean $(95 \%$ C.I.)

Table 4: Correlations between WHOQOL-Bref domains, SF score, QOLS score and clinical variables

\begin{tabular}{|c|c|c|c|c|c|}
\hline & WHOQOL-Physical & $\begin{array}{l}\text { WHOQOL- } \\
\text { Psychological }\end{array}$ & $\begin{array}{c}\text { WHOQOL- Social } \\
\text { Relations }\end{array}$ & $\begin{array}{l}\text { WHOQOL- } \\
\text { Environmental }\end{array}$ & $\begin{array}{c}\text { Total WHOQOL } \\
\text { Score }\end{array}$ \\
\hline SF 36-Physical Health & $0.3733 * *$ & $0.3286 * *$ & $0.2460 * *$ & $0.3386 * *$ & $0.4001 * *$ \\
\hline SF36-Mental Health & $0.5200 * *$ & $0.5895 * *$ & $0.5100 * *$ & $0.5862 * *$ & $0.6844 * *$ \\
\hline SF36-Role Limitations & $0.3654 * *$ & $0.3427^{* *}$ & $0.3513 * *$ & $0.3547^{* *}$ & $0.4428 * *$ \\
\hline Total SF36 Score & $0.5166 * *$ & $0.5248 * *$ & $0.4727 * *$ & $0.5321 * *$ & $0.6372 * *$ \\
\hline QOLS Score & $0.425 I^{* *}$ & $0.6552 * *$ & $0.6492^{* *}$ & $0.7130 * *$ & $0.7545^{* *}$ \\
\hline Haemoglobin & $0.3444 * *$ & $0.1908 * *$ & $0.1607^{* *}$ & $0.1752 * *$ & $0.276 I^{* * *}$ \\
\hline $\begin{array}{c}\text { Lactate } \\
\text { Dehydrogenase }\end{array}$ & $-0.3355^{* *}$ & $-0.1202^{*}$ & $-0.2017^{* *}$ & $-0.1512^{* *}$ & $-0.2550 * *$ \\
\hline
\end{tabular}

$* \mathrm{P}<0.05, * * \mathrm{P}<0.01$, based on Student's $\mathrm{t}$ test 
compared favourably with other studies. The Cronbach's alpha for each of its domains were large, except for WHOQOL-Social relations, which is similar to other large, multicentre trials [32], and may be because it consists of only three items. The ceiling effects for WHOQOL-Social relations were also high similar to studies in patients with chronic obstructive airway disease where the ceiling effect was $5.2 \%$ [27]. In fact the WHOQOL-Bref showed lower effects than the SF-36, as the latter had high ceiling effects for two of its domains.

The instrument was able to discriminate between groups experiencing different frequencies of painful crises. Pain is a major indicator of health-seeking and hospitalization in these patients $[38,39,42-45]$, and those with frequent painful crises have shown poorer QOL in past studies $[9,23]$. The WHOQOL-Bref has shown significantly lower scores in those who have more frequent painful crises. This mirrors original work by Skevington [46], which has shown the sensitivity of the WHOQOL instruments to pain states.

The WHOQOL-Bref score had fair convergent validity, and the fact that it did not have stronger correlations with the SF-36 and QOLS suggests that while it does share some overlap with these existing measures, it assesses a unique aspect of quality of life not assessed by the either the SF-36 or the QOL. All domains of the WHOQOL-Bref had greatest correlations with SF-mental health and secondly with the total SF-36 score. This may be due to the fact that SF-physical health is a more objective measure whereas the WHOQOL-physical health is a purely subjective measure. This was mirrored in the study comparing the WHOQOL-Bref with SF-36 in patients with stroke [41], where the SF-physical health showed low correlations with most domains of the WHOQOL.

WHOQOL-physical health has significant correlations with more objective clinical variables, i.e. haemoglobin levels and LDH. Lower haemoglobin and higher LDH levels are known to be associated with more severe SCD experience $[44,47-49]$. The expected relationships therefore, between WHOQOL-physical health and these clinical parameters have been shown in this study. Similarly, the WHOQOL-psychological health has shown good convergent validity as evidence by its moderate correlation with SF-mental health.

Not unlike past research, the present study has also employed a cross-sectional design to study QOL in SCD, and so is limited in its ability to examine the stability or responsiveness to change in QOL in these patients. Future research could examine how their QOL fluctuates with changes in their health, as well as how the latter affect testretest reliability of QOL instruments.
In conclusion, the WHOQOL-Bref has shown fairly good utility in this specific disease population. It also compares favourably to other generic instruments to measure QOL such as the SF-36 and QOLS.

\section{Competing interests}

The authors declare that they have no competing interests.

\section{Authors' contributions}

All authors have contributed substantially to study design, data collection, analysis of data and preparation of the manuscript. All authors have also read and approved the final manuscript.

\section{Acknowledgements}

The authors would like to thank all the patients who participated so willingly in the study.

\section{References}

I. Serjeant GR, Serjeant BE: Sickle Cell Disease. Third edition. Oxford: Oxford University Press; 2001.

2. McCaw-Binns A, Alexander SF, Lindo JL, Escoffery C, Spence K Lewis-Bell K, Lewis G: Epidemiologic transition in maternal mortality and morbidity: new challenges for Jamaica. Int J Gynaecol Obstet 2007, 96(3):226-232.

3. Barton EN, Sargeant LA, Samuels D, Smith R, James J, Wilson R, Smith $\mathrm{F}$, Falconer $\mathrm{H}$, Yeates $\mathrm{C}$, Smikle MF, et al.: A survey of chronic renal failure in Jamaica. West Indian Med J 2004, 53(2):8I-84.

4. Escoffery CT, Shirley SE: Causes of sudden natural death in Jamaica: a medicolegal (coroner's) autopsy study from the University Hospital of the West Indies. Forensic Sci Int 2002, 129(2): I|6-12I.

5. Wierenga KJ, Hambleton IR, Lewis NA: Survival estimates for patients with homozygous sickle-cell disease in Jamaica: a clinic-based population study. Lancet 200I, 357(9257):680-683.

6. Wison Schaeffer J], Gil KM, Burchinal M, Kramer KD, Nash KB, Orringer E, Strayhorn $D$ : Depression, disease severity, and sickle cell disease. J Behav Med 1999, 22(2): I I5- 126.

7. Ohaeri JU, Shokunbi WA, Akinlade KS, Dare LO: The psychosocial problems of sickle cell disease sufferers and their methods of coping. Soc Sci Med 1995, 40(7):955-960.

8. Jacob $\mathrm{E}$ : The pain experience of patients with sickle cell anemia. Pain Manag Nurs 200I, 2(3):74-83.

9. Anie KA, Steptoe A, Bevan DH: Sickle cell disease: Pain, coping and quality of life in a study of adults in the UK. BrJ Health Psychol 2002, 7(Part 3):33I-344.

10. Anie KA, Steptoe A: Pain, mood and opioid medication use in sickle cell disease. Hematol J 2003, 4(I):7I-73.

II. Bodhise PB, Dejoie M, Brandon Z, Simpkins S, Ballas SK: Non-pharmacologic Management of Sickle Cell Pain. Hematology 2004, 9(3):235-237.

12. Strickland OL, Jackson G, Gilead M, McGuire DB, Quarles S: Use of focus groups for pain and quality of life assessment in adults with sickle cell disease. I Natl Black Nurses Assoc 200I, I2(2):36-43.

13. Kater AP, Heijboer H, Peters M, Vogels T, Prins MH, Heymans HS: [Quality of life in children with sickle cell disease in Amsterdam area]. Ned Tijdschr Geneeskd I999, I 43(4I):2049-2053.

14. Thomas VJ, Taylor LM: The psychosocial experience of people with sickle cell disease and its impact on quality of life: Qualitative findings from focus groups. $\mathrm{Br} J$ Health Psychol 2002, 7(Part 3):345-363.

15. Anie KA: Psychological complications in sickle cell disease. $\mathrm{Br}$ J Haematol 2005, I 29(6):723-729.

16. Maxwell K, Streetly A, Bevan D: Experiences of hospital care and treatment seeking for pain from sickle cell disease: qualitative study. Bmj 1999, 3 I 8(7 I 98): I 585-1590.

17. Midence K, Fuggle P, Davies SC: Psychosocial aspects of sickle cell disease (SCD) in childhood and adolescence: a review. $\mathrm{Br}$ J Clin Psychol 1993, 32(Pt 3):27I-280. 
18. Asnani M: The Prevalence of Depression in Sickle Cell Disease in the Jamaican Cohort. Kingston, Jamaica.: University of the West Indies; 2004.

19. Brown RT, Kaslow NJ, Doepke K, Buchanan I, Eckman J, Baldwin K, Goonan B: Psychosocial and family functioning in children with sickle cell syndrome and their mothers. J Am Acad Child Adolesc Psychiatry 1993, 32(3):545-553.

20. Gil KM, Abrams MR, Phillips G, Keefe FJ: Sickle cell disease pain: relation of coping strategies to adjustment. J Consult Clin Psychol I989, 57(6):725-73I.

21. Hasan SP, Hashmi S, Alhassen M, Lawson W, Castro O: Depression in sickle cell disease. I Natl Med Assoc 2003, 95(7):533-537.

22. Thomas VJ, Hambleton I, Serjeant G: Psychological distress and coping in sickle cell disease: comparison of British and Jamaican attitudes. Ethn Health 200I, 6(2):I29-136.

23. McClish DK, Penberthy LT, Bovbjerg VE, Roberts JD, Aisiku IP, Levenson JL, Roseff SD, Smith WR: Health related quality of life in sickle cell patients: The PiSCES project. Health Qual Life Outcomes 2005, 3(I):50.

24. Asnani M, Lipps G, Reid M: Validation of the SF-36 in Jamaicans with Sickle Cell Disease. Psychology, Health \& Medicine (accepted for publication April 2009) .

25. WHOOOL Group: The World Health Organization Quality of Life Assessment: development and general psychometric properties. Soc Sci Med 1998, 46(I 2): I 569 - I585.

26. WHOQOL Group: Development of the World Health Organization WHOQOL-BREF quality of life assessment. Psychol Med I 998, 28(3):55 I-558.

27. Liang WM, Chen JJ, Chang CH, Chen HW, Chen SL, Hang LW, Wang JD: An empirical comparison of the WHOQOL-BREF and the SGRQ among patients with COPD. Qual Life Res 2008, I7(5):793-800.

28. Skevington SM: Advancing cross-cultural research on quality of life: observations drawn from the WHOOOL development. World Health Organisation Quality of Life Assessment. Qual Life Res 2002, I I(2): I35-I44.

29. Sherlock P, Bennete $H$ : The story of the Jamaican people. Kingston, Jamaica: lan Randle Publishers; 2000.

30. Burckhardt CS, Anderson KL: The Quality of Life Scale (QOLS): Reliability, Validity, and Utilization. Health Qual Life Outcomes 2003, I(I):60.

31. United Nations Development Programme: Human Development Report, Jamaica. 2008 [http://www.jm.undp.org/files/ lamaica2ndNHDR.pdf].

32. Skevington SM, Lotfy M, O'Connell KA: The World Health Organization's WHOQOL-BREF quality of life assessment: psychometric properties and results of the international field trial. A report from the WHOQOL group. Qual Life Res 2004, I 3(2):299-310.

33. Asnani M, Lipps G, Reid M: Component structure of the SF-36 in Jamaicans with Sickle Cell Disease. West Indian Medical Journal 2007, 56(6):49I-497.

34. Flanagan JC: Measurement of quality of life: current state of the art. Arch Phys Med Rehabil 1982, 63(2):56-59.

35. StataCorp: Stata 8.2. 4905 Lakeway Drive, College Station, Texas 77845 USA; 1984.

36. WHOQOL Group: Introduction, administration, scoring and generic version of the assessment- field trial version. 1996.

37. Bland JM, Altman DG: Cronbach's alpha. Bmj 1997, 3 I 4(7080): 572 .

38. Smith WR, Bovbjerg VE, Penberthy LT, McClish DK, Levenson JL, Roberts JD, Gil K, Roseff SD, Aisiku IP: Understanding pain and improving management of sickle cell disease: the PiSCES study. I Natl Med Assoc 2005, 97(2): | 83-193.

39. Smith WR, Penberthy LT, Bovbjerg VE, McClish DK, Roberts JD, Dahman B, Aisiku IP, Levenson JL, Roseff SD: Daily assessment of pain in adults with sickle cell disease. Ann Intern Med 2008, I 48(2):94-I0I.

40. Stuart MJ, Nagel RL: Sickle-cell disease. Lancet 2004, 364(9442): $1343-1360$

41. Unalan D, Soyuer F, Ozturk A, Mistik S: Comparison of SF-36 and WHOQOL- 100 in patients with stroke. Neurol India 2008, 56(4):426-432.

42. Baum KF, Dunn DT, Maude GH, Serjeant GR: The painful crisis of homozygous sickle cell disease. A study of the risk factors. Arch Intern Med 1987, 147(7): |23|-1234.
43. Rees DC, Olujohungbe AD, Parker NE, Stephens AD, Telfer $P$, Wright J: Guidelines for the management of the acute painful crisis in sickle cell disease. BrJ Haematol 2003, I 20(5):744-752.

44. Serjeant GR: The dilemma of defining clinical severity in homozygous sickle cell disease. Curr Hematol Rep 2004, 3(5):307-309.

45. Solomon LR: Treatment and prevention of pain due to vasoocclusive crises in adults with sickle cell disease: an educational void. Blood 2008, I I I(3):997-I003.

46. Skevington SM: Investigating the relationship between pain and discomfort and quality of life, using the WHOQOL. Pain 1998, 76(3):395-406.

47. Kato GJ, McGowan V, Machado RF, Little JA, Taylor Jt, Morris CR, Nichols JS, Wang X, Poljakovic M, Morris SM Jr, et al.: Lactate dehydrogenase as a biomarker of hemolysis-associated nitric oxide resistance, priapism, leg ulceration, pulmonary hypertension, and death in patients with sickle cell disease. Blood 2006, I07(6):2279-2285.

48. Steinberg $\mathrm{MH}$ : Predicting clinical severity in sickle cell anaemia. BrJ Haematol 2005, I 29(4):465-48I.

49. Cumming V, King L, Fraser R, Serjeant G, Reid M: Venous incompetence, poverty and lactate dehydrogenase in Jamaica are important predictors of leg ulceration in sickle cell anaemia. $\mathrm{Br}$ J Haematol 2008, 142(1): I| $9-125$.
Publish with BioMed Central and every scientist can read your work free of charge

"BioMed Central will be the most significant development for disseminating the results of biomedical research in our lifetime. "

Sir Paul Nurse, Cancer Research UK

Your research papers will be:

- available free of charge to the entire biomedical community

- peer reviewed and published immediately upon acceptance

- cited in PubMed and archived on PubMed Central

- yours - you keep the copyright

Submit your manuscript here:

http://www.biomedcentral.com/info/publishing_adv.asp
BioMedcentral 